\title{
OBITUARIES
}

\section{Dr. L. B. Turner}

Dr. Laurence Beddome Turner, who died in a nursing home on January 28, was born at Charlton, Kent, on April 6, 1886. He was among the earliest of the advanced engineers in Great Britain engaged in research on wireless techniques as applied to practical signalling by continuous electromagnetic waves using the thermionic valve.

L. B. Turner was educated at Bedford Grammar School and King's College, Cambridge, obtaining honours in the Mechanical Sciences Tripos in 1907. Following a year's research in the Engineering Laboratory, he was awarded the John Winbolt Prize for an essay on his work. After acquiring practical experience at the works of Messrs. Siemens Brothers, Woolwich, and at Siemens and Halske in Berlin, he entered the Post Office as an assistant staff engineer in 1910. Here he was engaged in experimental work, and in the design of ship and shore stations. During the First World War he was at the Army's Signal Experimental Establishment at Woolwich, where he designed field apparatus, including portable transmitters for short wave-lengths.

At the end of the War he left the Post Office to return to Cambridge as Fellow of King's Collego and director of studies in engineering. Later he became a technical adviser on the Postmaster-General's Committee concerned with the establishment of a world-wide long-wave wireless chain, of which the Hillmorton Station near Rugby, and that at Abu Zabal near Cairo formed the first link. While the Rugby Station, still in use, has proved to be an outstanding success as a reliable sending station of worldwide range, the principle of the chain as a whole was overtaken by the development of the short-wave beam system by Franklin and Marconi.

L. B. Turner became a corporate member of the Institution of Electrical Engineers in 1920, and was one of the founder members of the Wireless Section of the Institution. He was chairman of the Section for the session 1922-23, and in his inaugural address he gave an excellent review of the development of the thermionic valve during the early years of its application to wireless signalling. As a supplement to the address he gave an interesting account of some original work on spontaneous fluctuations in valve amplifiers. He patented in 1920 a two-valve circuit arrangement designed to amplify weak radio signals at the same time reducing the strength of prevailing atmospheric disturbances.

The remarkable developments in wireless communication during the First World War demanded new works of reference, and L. B. Turner was one of the first in the field with his Outline of Wireless, published in 1921. This was followed ten years later (1931) with his more comprehensive volume entitled: Wireless: a Treatise on the Theory and Practice of High-Frequency Electric Signalling. Both books were noteworthy for their clarity of description of the fundamental principles of the subject, with an adequate presentation of practical details.

The versatility of Turner's interests was, however, well demonstrated by a paper he read before the Institution of Electrical Engineers in 1937 on the principles of design of electrical thermostats, and containing a description of a mains-operated isothermal chamber constant to one-thousandth of a degree Centigrade.

During the Second World War he was with the Admiralty Signals Establishment at Portsmouth, where his work was excellent if less well known than during the First World War. He returned afterwards to Cambridge, where he was able to devote himself to further rosearch. He was made a University reader in 1948.

R. L. Smith-Rose

\section{Mr. A. Warmisham}

Arthur Warmisham, who died on November 10, read mathematics in the University of Manchester under Prof. H. Lamb and Mr. (later Sir) Charles Darwin, and graduated M.Sc. In 1912 he entered the firm of Taylor, Taylor and Hobson (now Rank Taylor Hobson) as optical designer. In those days the number of university men (apart from chemists) entering industry was small-. of mathematicians practically none. There was no technical training in optical design apart from a small course for sight-testing opticians at the Northampton Polytechnic (now the Northampton College of Advanced Technology), so that English optical designers (such as H. Dennis Taylor) had to teach themselves. So it was with Warmisham; practically the only books were Dennis Taylor's System of Applied Optics, based on Coddington, and von Rohr's Formation of Images in Optical Instruments.

With the First World War came the development of aircraft and the use of photography for reconnaissance. It was found that at the aperture $(f / 4 \cdot 5)$ and field $\left(35^{\circ}\right)$ most suitable, English photographic lenses were inferior to one German lens (which, of course, was no longer available). It happened that Warmisham had been examining the 4-element type of anastigmat and had developed a lens remarkably free from coma over just this field and at this aperture, and this property was valuable in improving contrast in the image, facilitating the recognition of detail. The lens (and others) was tested by the Royal Flying Corps side-by-side with the German and found to be superior. It was accordingly extensively used in air photography, and appropriately named the Aviar.

After the War his task was to adapt the Aviar to professional use, and it became very popular. An apochromatic form was designed for process work.

Improved standards of definition were demanded by the cinematograph industry both for taking and projecting lenses. Warmisham designed a remarkable series of projection lenses of greater aperture to give the brighter picture required for the larger cinemas which were then being built. Another demand came with the introduction of talking films. Hitherto, variation in the scale of the image (for 'close-ups', etc.) was made by moving the camera to and fro, with visual focusing. This was objectionable when sound was recorded. All extraneous noises had, of course, to be eliminated. Warmisham visited the United States and there invented a lens of variable focal length. By variation of the separation of the components not only was the focal length changed (and with it the scale of the picture), but the image was kept automatically in focus throughout the range of movements, without shift of the camera. This was not the first 'variable focus' lens but the first to achieve an acceptable standard of definition over a wide range of focal lengths, at high aperture. 'Zoom' lenses, as they are called, are now widely used in cinematography, television and still photography and projection.

Warmisham published little, but he was a prolific inventor, as the files of the Patent Office show-in fact, he invented more than he could develop to marketable form. Many of to-day's well-known optical designers received their early training under his guidance, and the wide use and adaptation of his methods under presentday conditions in Great Britain and overseas is a tribute to his contribution to the art.

'A. W.', as he became known, was no respecter of persons and had a caustic yet humorous way of expressing somewhat candid opinions, but these were given with a Puckish grin that disarmed resentment. H. W. LEe 